\author{
MARTA M. VUKOTIĆ LAZAR ${ }^{1}$ \\ UNIVERSITY OF PRIŠTINA IN KOSOVSKA MITROVICA \\ FACULTY OF PHILOSOPHY \\ DEPARTMENT OF HISTORY OF ART \\ OLIVERA S. MARKOVIĆ-SAVIĆ ${ }^{2}$ \\ UNIVERSITY OF PRIŠTINA IN KOSOVSKA MITROVICA \\ FACULTY OF PHILOSOPHY \\ DEPARTMENT OF SOCIOLOGY
}

\title{
CULTURAL POLICY AND MEMORY OF THE FIGHTERS OF THE PEOPLE'S LIBERATION WAR: THE CENTRAL ROLE OF THE ARMY IN POLITICAL LEGITIMATION OF THE NEW POLITICAL STRUCTURE
}

\begin{abstract}
The fighters of the People's Liberation War (PLW) enjoyed the social prestige and the monuments of the killed fighters served the role of the ideological interests of the ruling class at the time. The aim of this paper is to show the link between the alive social actors and the chosen dead ones (fighters of the PLW, partisans) through the use of the anthropological anxiety of the cessation of life through metaphorical immortality and eternal memory. Essentially, this was the illusion for ideological foundation, special thematic and ideological orientation of sculptures within the public space. Via symbolic contents, such as monuments in this case, death is shown as the transition, that is, new beginning of life and not its end. Active involvement of a number of artists from all parts of former Yugoslavia with-
\end{abstract}

marta.vukotic@gmail.com

markovic.olivera@gmail.com

This paper was submitted on August $17^{\text {th }}, 2020$ and accepted for publication at the meeting of the Editorial Board held on September $25^{\text {th }}, 2020$. 
in the units of the Partisan army in the PLW is the phenomenon which unequivocally testifies about the link of their political commitment and artistic creation, which also got particularly strong momentum immediately after the Liberation. The most important social task in the Socialist Federal Republic of Yugoslavia (SFRY) was nurturing of the revolutionary tradition, especially seen in the erection of memorials, then in (re)naming of the towns with Tito's name or the names of the local heroes, as well as streets, schools, factories, but also in organizing marches to places where the famous battles and Partisan sessions during the PLW occurred, etc. This paper, among other things, deals with extremely fruitful production of the sculptors in the liberated country, especially from the aspect of extensive social orders, which at the same time encouraged and enabled fast and diverse development of the public monuments within urban areas on the ground of the whole former Yugoslavia, whose modus operandi was reshaping of the political and ideological map of The New Yugoslavia and ideological and political battle with "relapses of the past".

KEYWORDS: fighters; PLW; Partisans; SFRY; FPRY; ideology; sculpture; public urban areas.

\section{INTRODUCTION}

The relationship of society to war is paradoxical. It is hard to imagine that somebody could advocate for war in the sense of organized murders of other people, but the fascination and glorification of a certain war and its victims are omnipresent starting from history textbooks, then in books, television and culture and art in public spaces. What is also paradoxical is the fact that the legacy of war is the guarantor of peace. Thus, every call to war is clothed in and justified by ideals such as peace, freedom, brotherly love, democracy.

Even though it is often considered that war is almost the natural state of the mankind just restrained by society (Hobbes, Machiavelli), the truth is that most people avoid war and violence. War in the sense we know it today, that is, as organized violence is a modern social phenomenon.

"Having in mind that violence is not inborn in humans, thus automatically its successful use in mass proportions requires highly developed organizational mechanisms of the social control and well-articulated and institutionally fixed ideological doctrines which can justify such state" (Malešević, 2011, p. 19). 
Without a developed social organization, there is no organized violence. On the other hand, it was exactly the development of modern army and its bureaucratic structure and organization that were the pillars of the development of the bureaucratization of modern societies. As Weber (1976) outlines, the middle part of bureaucracy is discipline, and "military discipline gives birth to every kind of discipline". However, it would not be possible for any organization to use force and discipline in the long run if its actions are not justified within the broad layers of society. Therefore, as Malešević (2011) states, every organization needs legitimizing ideology.

This paper deals with war and its social symbolic as the pillar of the ideology and bureaucratic organization of an authority and deals with it on a particular case of the foundation of the new Yugoslav state on the legacy of the People's Liberation War, where one important fact was not ignored, which is that there are many examples like this throughout history, moreover, that they are predominant in modern history. The People's Liberation War and its fighters stood for the pillars of the legitimation of the new government based on the victory in the Second World War. The army was a special medium, which is why it became the central state institution from where the whole ideological corpus was promoted: from brotherhood and unity, via socialist self-management until Tito's charisma. This was not the specificity of the Yugoslav new government back then; the symbolic instrumentalization of war victims in the form of the public monuments can be found since the $19^{\text {th }}$ century. The dominant social function of public monuments is not reverence for the dead but addressing to the living as Kuljić explains, "it is about the instrumental forget-me-not" (Kuljić, 2014, p. 273).

\section{CARE FOR SURVIVORS}

The liberation period welcomed a great number of fighters of the PLW, a great number of wounded and a great number of families whose breadwinners died in the war. Social care of this large social group immediately imposed as a priority of the new government. The importance of care of this large group was in the need for legitimation and support based on the victory in the war but also as 
proof that social care of the vulnerable categories of the population would be the priority for the new government.

Immediately after the war, the question of the war invalids and families of the fallen fighters were under the military jurisdiction so that the great work of enumeration and recognition of the fighters' status, war invalids' status and families of the fallen fighters' status, status of the disappeared and deceased fighters would be dealt with as soon as and more efficient as possible.

The National Committee for the Liberation of Yugoslavia (NCLY), that is, its President Tito enacted the first regulations on the protection of the military invalids (one-time financial aid) after the liberation of Belgrade and greater parts of Serbia in the fall of 1944 (Маловић, 2011, p.116). As soon as the second half of 1944, homes for accommodation and care for war invalids for all those who did not have where to go after treatment were opened. Immediately after the end of the war, in 1945, the so-called Disability Department in the Ministry of Defense of the Federal People's Republic of Yugoslavia (FPRY) was formed. This Department existed within this Ministry up until the complete transfer of the jurisdiction to civilian authorities, that is, up until the beginning of 1949. Within the jurisdiction of this Department, the following categories were dealt with: war invalids of the PLW of Yugoslavia and war invalids from the previous wars of Serbia and Montenegro from 1912-1918, war invalids of the Kingdom of Yugoslavia from the April War of 1941, as well as the families of the killed, deceased, and missing fighters. Peacetime war invalids were also under the jurisdiction of this Department, whereas, civilian disabled workers and civilian invalids were not as they remained under the jurisdiction of the Ministry of Social Policy (Маловић, 2011a, 2011b) ${ }^{3}$. The first forms of aid were one-time financial aid, and then, regular monthly cash income was introduced which lasted until the problem of social care of these families was regulated by law passed on May 25, 1946.

Military authorities despite many difficulties, such as a war-torn country and the majority of it being an illiterate population, dealt with the questions of care of war invalids and families of fallen fighters pretty efficiently. Already in the first half of 1946, 35.318 civilian invalids were acknowledged. According this record, financial aid was paid and necessary orthopedic aids were assigned. The

3 It should be noted that members of the Yugoslav army in the homeland and Ravna Gora Movement were not taken care of; their rights were recognized only in 2005. 
Ministry of Defense had one important job - to elaborate the law as the most urgent task - acts and regulations had to be passed, then, it was necessary to form military disability boards (the Disability Department and Disability Committee at the headquarters of each army and at the each command of the military area). All this was difficult to manage, and due to numerous difficulties, disability officers, who were all military members at the same time, were introduced in every County People's Committee. In the report, detailed testimonies about the problems which disability bodies faced are found, for example, People's Committees were not fully cooperative due to the fact that Committees did not consider dealing with these matters their duties since these matters had been under the jurisdiction of the Ministry of Defense. Nevertheless, after the initial difficulties the result was achieved and until the 1st November 1948 the total number of acknowledged cases with disability properties was 293.150 , both civilian and family invalids (decreased for the number of received but also rejected properties), out of which 82.258 civilian and 210.892 family invalids.

When this job came to an end, an order was issued "for all the war invalids from previous wars and from the captivity to undergo a medical re-examination under the regulations and guidelines which are valid now" (Маловић, 2011a, p. 400), in fact, an audit was being done and 28.544 cases were audited, and the 3.207 invalids lost the disability status (around 20\%).

The disabled exercised the right to: health care (including spas and rehabilitation centers); within the homes for the disabled (there were 27 in 1945, but 14 in 1948) professional trainings of war invalids were organized for performing old or new jobs, the so-called, retraining. According to the Report (Маловић, 2011a) within the homes for the disabled 4.134 disabled persons graduated from schools such as gymnasium, agricultural high school, craft and trade school; 7.797 disabled persons completed courses and $7.202 \mathrm{crafts}^{4}$. Besides the homes for the disabled, it was regulated that all state, collective and private companies employ war invalids for training and retraining.

Alongside with dealing with qualifications of the disabled, in parallel the problem of employment of their employment had to be dealt with. The result was that in 1947 the total number of disabled employees was 29.000. The new government was aware of all the

4 Even though many disabled asked to be qualified for the administrative jobs, it was hard for them because many of them did not have any education at all. 
difficulties of dealing with social problems of the disabled, due to which it decided to place dealing with this hard and demanding problem under the military jurisdiction which had the power to implement decisions in places where there was resistance, and it reported directly to Tito (who was also the Minister of Military Administration).

Due to the great demand for orthopedic aids, orthopedic industry was being developed. Even though there are reports about the great advancement in this industry during the period between 1945-1948 (for example, the production was increased for 819\%) "our orthopedic industry does not satisfy all the needs of the country because we have a great number of the work invalids and other citizens disabled during the war", page 408. The development of this industry directly implicated the number of the disabled caused by the greatest war in the human history, alongside even the greater number of the killed.

In November 1948, the jurisdiction of war invalids was transferred from military-disabled authorities to civilian social welfare authorities. As Маловић states the main reason for this transition stated in all acts was that the military authorities successfully dealt with all problems of the disabled matter with resolving the greatest number of care cases of the war invalids so this work could freely be taken over and performed by civilian social welfare authorities. However, the same author considers that the most important reason was tacit, that is, this transition should be viewed in the light of deteriorating relationships and threatening of the armed conflict with the USSR, because of which it was necessary to create the stronger and more mobile army and to enable the more efficient command, whereby the jobs of war veterans represented a ballast to be disposed of (Маловић, 2011a, p. 411). Such were the care and protection of the disabled and other protected persons transferred from the Ministry of Defense to the Social Welfare Committee and its bodies. Officers and military officials were replaced with civilians, and attendants remained in their job positions.

Together with the state authorities that took care of the law regulation as well as its enforcement, the leading role in the care of the fighters of the PLW had the organization Association of Fighters of the People's Liberation War of Yugoslavia (AFPLW). ${ }^{5}$

After the founding assembly of the AFPLW on September 30, 1947 and the approval od the Ministry of Internal Affairs of the Federal People's Republic of Yugoslavia (FPRY) the forming of Republic 
Unions followed. The first congress of the Association of Fighters of Serbia took place on May 9, 1948. All forms of work and action were aligned with the Program of the League of Communists of Yugoslavia and the Program principles of the Socialist Alliance of Working People of Yugoslavia. ${ }^{6}$ The Alliance performed diverse activities in its work, which was determined by the Status and Regulations of the Alliance. Thus, the primary activities were: records and personnel policy of the membership, nurturing and developing of the revolutionary traditions of the PLW, care of erection of new memorials of the PLW and thus of preservation and protection of the existing ones. The members of the Alliance besides the fighters could be persons who actively helped the NOR, as well as the captured activists who besides the torture remained on the war line, interns or persons in forced labor for aiding the PLW, as well as those who fought against fascism within another resistance movement (Spanish, French and others). All this made the care of the fighters seem comprehensive and at a very high level of organization.

\section{CULTURAL POLICY IMMEDIATELY AFTER THE LIBERATION AND MEMORY OF THE FIGHTERS OF THE PEOPLE'S LIBERATION WAR}

Due to the victories of the allied authorities on the Eastern and Western fronts, but also the units of the People's Liberation Army (PLW) on the Yugoslav battlefield, anti-occupation mood gained new incentives and it affected ever-wider layers of the population. PLW was given the opportunity to merge with the forces of the Red Army in Serbia and thus to form a unique front of the Soviet-Yugoslav military force on the Balkan Peninsula. (Marjanović, 1974, p. 550).

Belgrade occupied an important place in both Red Army strategy and People's Liberation Army of Yugoslavia strategy (PLAY). For

5 See: Jakir, A. (2019). "Monuments are the Past and the Future." Political and administrative mechanisms of financing the monuments during the time of the Socialist Yugoslavia. Journal of Contemporary History (JCH) Vol. 51 No.1, 151-182. DOI: https://doi.org/10.22586/csp.v51i1.8293; Šimpraga, S. Taken over from the web site: ,Jugoslavenski poučak”. H-ALTER, 30.1. 2015. http://h-alter.org/ vijesti/jugoslavenski-poucak.

6 Statut of AFPLW, according to (?ukić, 2006) 
the People's Liberation Movement (PLM) Belgrade, as the capital of Yugoslavia and Serbia, was significant for various reasons but priority tasks were to disable the reactionary forces working on the prevention of spreading of NOP and establishing of the old regime and monarchy on the city area.

A significant role in organization and work of the CPY (the Communist Party of Yugoslavia) in Belgrade and Serbia had the two family houses. The House of Vladislav Ribnikar at 10/a Aleksandar Karađorđević Boulevard where the members of Politburo of the Central Committee of the Communist Party of Yugoslavia held the committee meeting on the July 4, 1941 at which they made the decision to raise an uprising of the People of Yugoslavia against the occupant. This day was later celebrated as the Fighters' Day. In this house, in the first days of the war, illegals were hiding, and for some time the Bilten vrhovnog štaba NOV i POJ (Bulletin of the Supreme Headquarters of PLW and PDY) were printed. ${ }^{7}$ Next, the House of Branko and Dana Maksimović at 12, Banjički Venac where the print shop of the CKKPJ (Central Committee of the Communist Party of Yugoslavia) was located and where the Bulletin of the Central Headquarters of the HOPJ, newspapers Glas and Proleter, proclamations of the CPY, reports, commands and other materials were printed. The painter, Đorđe Andrejević Kun worked at the printing house at the time and he made precise clichés in wood for the need of the illegals and their actions for forging various German documents, stamps, personal id cards, etc. ${ }^{8}$ Immediately after the Second World War, as a prominent personality, Kun was also highly positioned on the field of the social work amongst the artists. In the Association of Fine Artists of Serbia (AFAS), Association of Fine Artists of Yugoslavia (AFAY) as a professor and then as a rector of the Belgrade Academy of Arts.

His oil on canvass of great dimensions from 1946 named "Column" exhibited nowadays in the Palace of Serbia (once Federal Executive Council /SIV/) is a significant example of the war time topics and evoking memories to heroic partisan fight (Stevanović 1977. pp. 13-14, 55).

7 In this house, within the period of 1950 until 2003 the " 4 th July" Museum was situated. The Museum was opened on the 1st May 1950 and it belonged to the Belgrade Museums In 1982 it was included in "Josip Broz Tito" Memorial Centre and upon its abolition in 1996, it was included in the Museum of History of Yugoslavia.

8 In this house the Museum of the Secret PrintShop 


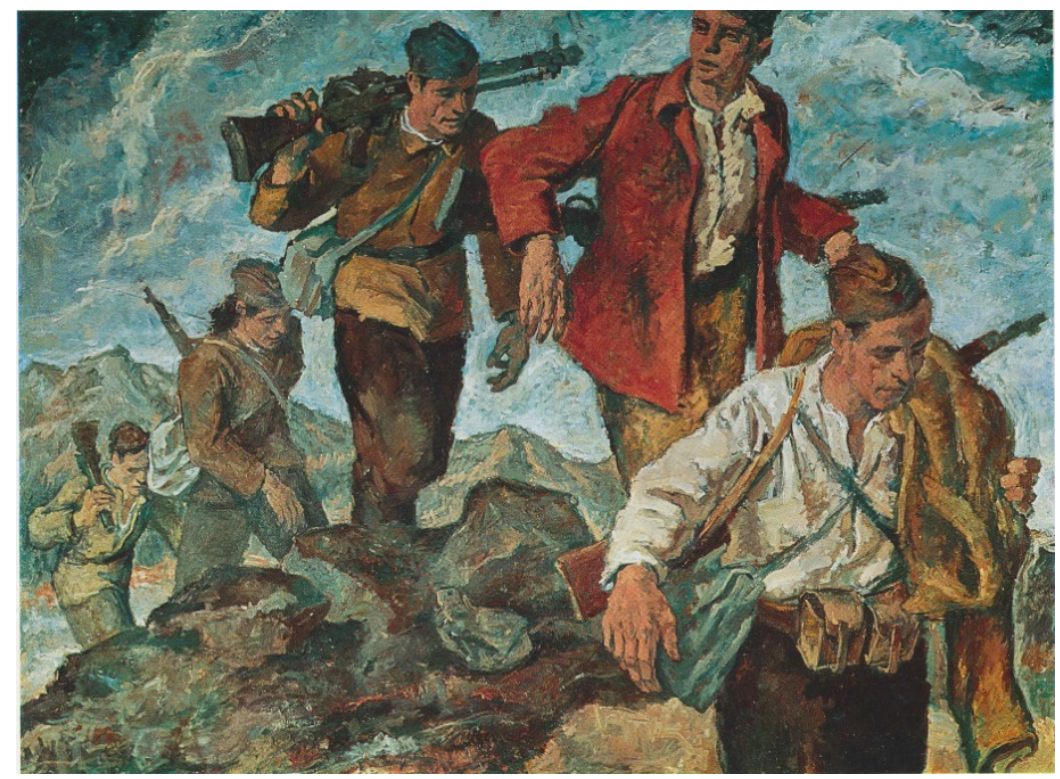

FIGURE 1: ĐORĐE ANDREJEVIĆ KUN, COLUMN, OIL ON CANVASS, 185X216CM, SIV, BELGRADE

During the street fights for the liberation of Belgrade, a large number of fighters of the NOVJ, Red Army, German soldiers, but also civilians were killed. Within the context, it is important to look back at the organized care of the wounded on the city area of Belgrade which would grow to be a developed and well-organized social care after the liberation in the New Yugoslavia, as was already stated in the Introduction. As early as in 1945, Tito announced, in his speech to the wounded in the hospital of the Second Army in Zagreb, taking special care about the protection of the war invalids (Маловић, 2011, p. 118).

The public authorities, with the aim of care, treatment, recovery of the wounded and exhausted partisan fighters, together with background military authorities organized hospitals as well as their supply of food and medical supplies, etc. Wounded fighters were also accommodated with families who took care of them, and civil hospitals were organized, too. Thus, one anti-fascist group gathered around Pera the Painter, which was the illegal name of the fighter Žarko Mrđenov, organized an infirmary in Belgrade, firstly named "Dressing Room and First Aid" and later "20th October" at 11, Vuk Karadžić St on which date it started working in 1944. Removal and burial of bodies of the killed was another of 
urgent tasks during the period of liberation of Belgrade. Special merits for preventing the spread of infection and epidemics in the city were attributed to Doctor Sergej Ramzin, Head of the Department for Public Hygiene of the Directorate for Social and Health Care of the Municipality of Belgrade (Lazić, 2014, p.11).

After the liberation of Belgrade on October 20, 1944, the building of the Officers' Home was handed over to the military partisan authorities. By the decision of the Supreme Headquarters of the Peoples' Liberation Army (NOV) and Partisan Detachments of Yugoslavia (POJ) on October 25, 1944 it became the Officers' Club, soon to become the House of the Yugoslav Army (JA) "as the central and representative cultural and educational institution of the Yugoslav Army" “(Đurić Mišina, Marić, 2017, p. 73).

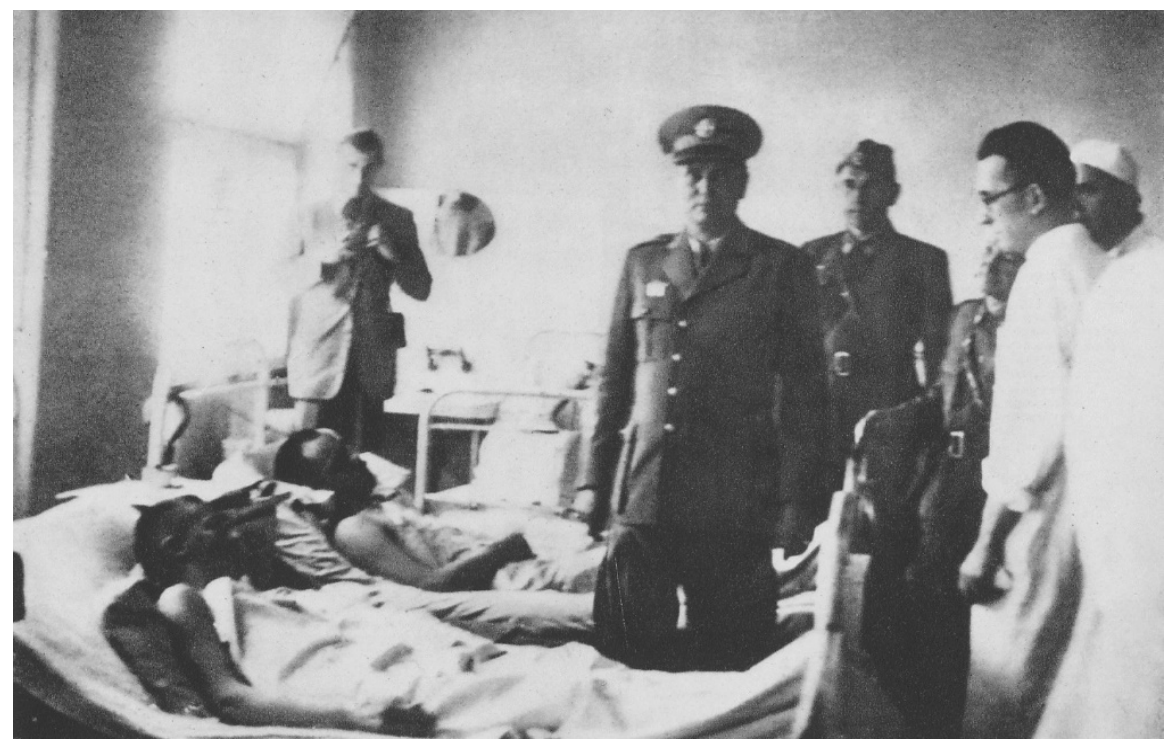

FIGURE 2: MARSHAL TITO VISITING WOUNDED FIGHTERS IN THE MAIN MILITARY HOSPITAL IN BELGRADE, $1^{\text {ST }}$ JANUARY 1945.

The city command was situated in the representative palace of pre-war Warrior's Home at 19 Braće Jugovića St in Belgrade. Since the inception of the idea about the founding of it, over the architectural contest for the building (1929-1931), sanctification of the cornerstone, building (1932) and upgrading (1939), as a place for creating notions of Yugoslav political and national identity, this building would survive on the political and ideological maps of Belgrade, Serbia and both Yugoslavias. Despite of the fact that all new authorities "until today recognized this" as the symbol of the previ- 
ous systems, the primary context of this building and the meaning of its erecting - to highlight the army as the central institution of the Yugoslav society - was not erased (Ignjatović 2005, p. 313).

The Home was erected based on the contest project of the architects Živko Piperski and Jovan Jovanović on the plot of the Velocipede Club given to the former warriors by the Municipality of Belgrade. It was modeled by social homes in Czechoslovakia and Poland and immediately, numerous associations and alliances were moved in: Association of reserve officers and warriors, Adriatic Guard, Association of Volunteers, Sokolska Matica, The Society of Friends of France, Shooting Association, Hunting Association, Swordsmen's Club and Actors' Association Fund. In order for the activities of the Warriors' home to become massive, in 1939 the Club for Reserve Officers and Fighters was formed as an independent body.

With bombing of Belgrade on April 6, 1941, the first chapter of the history of this building is finished.

The period from August 22, 1941 until September 26, 1944 during which the Warriors' Home (Veterans' Club Building) was the Gestapo Headquarters for the Balkans, and its premises on the lowest lever were used as a prison, for torture and killing of patriots is considered the darkest period in the history of this building which was and has been since its founding the nursery of culture (Đurić Mišina, Marić, 2017, p. 69)

The first chief of the Home of the Jugoslav Army was Branko Šotra, an academic painter, later a manager of the Military Museum in Belgrade during the period of its reform, then professor and the first rector of the Academy of the Applied Arts in Belgrade (19481956). The program of manifestations in the Home went according to plan and schedule similar to those from the period between the two world wars just waiting the new circumstances. The themes and the content of the program taking place on the premises until the end of 1944 were in the spirit of political propaganda and with the aim of popularization of the legacy of the PLW, and the Officers' club was also one of the buildings where the Women's Antifascist Front of Yugoslavia (WAFY) collected help for the fighters on the Syrmian Front. The first concert held in the Home by the military orchestra of the First Proleterian Division opened the door to all officers, their families, as well as the citizens. Political work that was going on in the Home of the Jugoslav Army was adjusted to the total political work of the Yugoslav Army (JA). Then, the first normative act was passed - the Order of the Minister of the National 
Defense of the Democratic Federal Yugoslavia (DFY) about the Reorganization of the Political and Educational and Cultural Work in the Yugoslav Army from the August 8, 1945, where, amongst other things, it was stated: "Political work has a task to educate fighters and managers in the spirit of loyalty to the war oath and further development of the NOB legacy!" (Đurić Mišina, Marić, 2017, p. 73). After this, education sections, artwork sections, photographic and film projections, physical activities, library, etc. were formed. Only during 1945, numerous lectures, concerts, film projections, cultural and artistic events with high attendance were held.

Three ceremonial academies were also held: the first one on the occasion of marking the end the war operations and signing of the capitulation on May 9, 1945; the second one for the Belgrade liberation anniversary on the October 20,1945 and the third one on the occasion of adopting the Declaration on the Proclamation of the Federal People's Republic of Yugoslavia (FPRY) on the November 29,1945 . On that occasion, compositions inspired by the People's Liberation Fight (NOB), such as cantata by Jovan Bandur "Yugoslav Partisan Rhapsody" containing 15 folk partisan songs were performed, dances such as polka and folk circle dance were danced, but in the end, the favorite was the so called "Kolo of Kozara" and the most popular film was "On Our Own Land" about the Yugoslav NOB, made in the Soviet-Yugoslav co-production (Đurić, Mišina, Marić, 2017, p. 73).

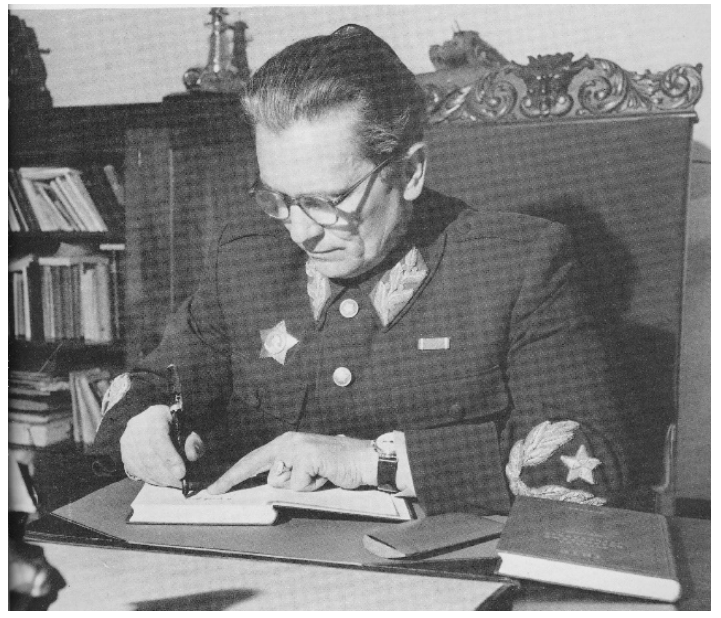

FIGURE 3: JOHN PHILLIPS, TITO, IN THE WHITE PALACE SIGNING HIS SPEECH COLLECTION IMMEDIATELY AFTER THE SECOND WORLD WAR 
With moving from the building of the Officers' Home to the building of the Warriors' Home (Veterans' Club Building), better conditions were obtained for more comprehensive work of the Yugoslav Army (JA). The name Warriors' Home was immediately changed into the Central Home of the Yugoslav Army directly before moving of the Army into the building on May 8,1946 and on the occasion of the celebration of the anniversary of the Victory Day. There, the partisan supreme commander, Marshal Josip Broz Tito gave a speech, and among other things stated:

"This is a solemn day for our Army when the Jugoslav Army Home, as a future center and nursery of the military improvement, political education, advancement of the cultural level, physical and versatile education and advancement of our leading staff, our officers, is being opened (...). Jugoslav Army Home will become a strong institution not only for the versatile education which will through you expand to the all Army of the Federal People's Republic of Yugoslavia (FPRY)" (Đurić Mišina, Marić, 2017, p.75)

With the official political break up with the Cominform (The Information Bureau of the Communist and Workers' Parties), the Soviet Union, and the Eastern Bloc countries in the 1948, during the period of 1950 until 1955 the Central Home of the YA raised the quality of work and expanded the fields of its activity connected to the domain of education and culture, and soon changed the name again and becomes the House of Yugoslav National Army (House of YNA).

What could be noticed immediately after 1945 was that the organization of the cultural and artistic life was based on the principle of the party's structure and hierarchy as well as that these two authorities-the state and the Party-were very quickly inextricably united. The Party thought soon spread to the whole society. In this sense, the cultural policy could only be led by the people proposed by the Communist Party of Yugoslavia, while it was less important from which social or cultural spheres they originated. Before the artists of all branches, there was a task to create an engaging form of art, include it in the state institutions, and with this "weapon" start the fight with the dissidents.

In connection to this, a clear message was sent from the capital of the newly formed FNRJ that the artists were assigned an important role in reshaping the old and creating the new society in the first place, in making new artistic and visual symbols of the new society. All this would also be announced at the founding congress AFAY in Zagreb in 1947 in the reports of the painters Đorde Andre- 
jević Kun and Đuro Tiljak. (Merenik, 2001, p. 26-27, Đorđević, 1969, p. 71)

The new ideology of the new Partisan government with specific political operations as a goal had the "erasing" of the civil values, conservatism, individualism, national interests, etc., and all this in favor of promoting of leftist ideas, revolutionism, collectivism, internationalism, etc.

In this context, the new government treated the art as an influential social, political and ideological means, as a social weapon whose aim was to act upon the field of visual and with the aim of (re)shaping of the inherited cultural model and the total change of the existing iconosphere in the accordance with partisan politics (Merenik, 2001, p. 25; Dragojević, 2015, p. 69).

CONCLUSION Immediately after the end of the Second World War the question of war invalids and their families was under the military jurisdiction so that the extensive work about the enumeration and acknowledging the status of the fighters, war invalids and families of the killed, missing and died fighters would be solved sooner and more efficient. That this social category was of great importance to the new government could be seen in the fact that the responsibility for resolving of their status was entrusted to the central state institution whose staff were the most confidential. Under the jurisdiction of the military authorities, the enumeration of the war invalids and families of the fallen fighters were done in spite of numerous difficulties (lack of evidence, illiterate population) within the relatively short period of a few years. Even though this jurisdiction under the military authorities did not last long (until 1948) the privileged position of this group remained as well as the constant affection of the supreme leader and the president.

The privileged position of the fighters of the NOR spoke in the favor of the thesis that their privilege in relation to others, before all else civil invalids, lay in their significance for ideological promotion of the new government. The foundations of a legitimizing ideology of the new government were laid in the Yugoslav Army: multinational content ("brotherhood and unity"), organized discipline, social mobility, of the lowest layers, but also social solidarity with socially vulnerable categories and the poorest (proletarian) layers. PLW actually represented the revolution upon which the new socialist government was based. This government primarily needed wide legitimacy and ideological "glue" which would hold 
together in one totality all parts of one relatively new country whose segments were in conflicts. One of rare common components was taking part in the war on the side of PLW led by Tito. On all foundations, it was necessary to disqualify all those forces, in all republics which had support in former authorities and which were in direct conflicts with PLW. New ideological values "brotherhood and unity" and socialist revolution were promoted, and later on the unique project of "Yugoslav self-government". On the other hand, in order for this ideology of new values to be founded in wide layers it was enabled by the omnipresent, widely spread network of central social military organization and its bureaucratic firm discipline.

The promotion of the new ideology immediately after the liberation was taking place under the watchful eye of the Army, as the central state institution, and in this sense, arts also received guidelines within which its official acting was required: social themes and left oriented theoretical and artistic practices. Thus, art was subordinated to the Party and its goals, and the official theory of the Yugoslav art was to shape the vision of the new society.

Đorđević, D. (1969). Socijalistički realizam 1945-1950. U: M. B. Protić (ur.), Jugoslovenska umetnost XX veka. 1929-1950: nadrealizam, postnadrealizam, socijalna umetnost, umetnost NOR-a, socijalistički realizam (68-81). Beograd: Muzej savremene umetnosti.

Jakir, A. (2019). „Spomenici su prošlost i budućnost“. Politički i administrativni mehanizmi financiranja spomenika za vrijeme socijalističke Jugoslavije. Časopis za suvremenu povjest (ČSP) Vol. 51 № 1, 151-182. DOI: https:// doi.org/10.22586/csp.v51i1.8293.

Jukić, M. (2006). Prilog poznavanju ustanova: Savez udruženja boraca Narodnooslobodilačkog rata Hrvatske (1947-1992). Arhivski vjesnik, 49 (1) 123-138.

Kuljić, T. (2014). Tanatopolitika. Beograd: Čigoja štampa.

Malešević, S. (2011). Sociologija vojske i rata. Zagreb: Jesenski i Turk.

Merenik, L. (2001). Ideološki modeli: srpsko slikarstvo 1945 - 1968. Beograd: Beopolis, Remont.

Šimpraga, S. Preuzeto sa internet stranice: ,Jugoslavenski poučak”. H-ALTER, 30. 1. 2015. http://h-alter.org/vijesti/jugoslavenski-poucak.

Weber, M. (1976). Privreda i društvo. Beograd: Prosveta.

Драгојевић, П. (2015). Уметност упркос рату:једна могућа стратегија ठа-

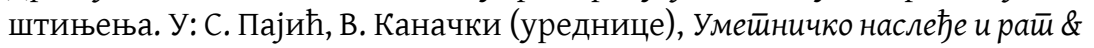


Музика и рай: IX међунарояни научни скуй (69-78). Крагујевац: Филолошко-уметнички факултет.

Ђурић Мишина, В., Марић, Н. (2017). Райнички gом. Београд: Медија центар одбрана.

Игњатовић, А. (2005). Између универзалног и аутентичног: о архитектури Ратничког дома у Београду. Гоgишњак іраgа Беоіраgа књ. LII, 313-330.

Лазић, С. (2014). Ослобођење Београда 70 година после кроз фондове и збирке Историјског архива Београда: каталог изложбе. У: С. Лазић (аутор изложठе и каталога), Ослобођење Беоіраga 70 ioguна йосле кроз фонgове и збирке Исӣоријскої архива Беоїраgа (9-69). Београд: Историјски архив Београда.

Маловић, Г. (2011а). Реферат о војној надлежности над ратним војним инвалидима у Југославији 1945-1948. Гласник Уgружења архивских раgника Рейублике срӣске. Бања Лука. (3) р. 385-412.

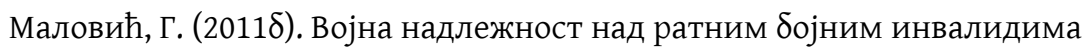
у Југославији 1945-1948. Војно-ист̄оријски іласник (1) стр. 114-144.

Марјановић, J. (1974). Ослобођење, Београда - престоница социјалистичке Југославије. У: В. Чубриловић (ур.), Исйорија Беоіраgа 3 (547-556). Београд: Просвета.

Стевановић, М. (1977). Ђорђе Анярејевић Кун. Београд: Српска академија наука и уметности, Издавачки завод Југославија.

LIST OF ILLUSTRATIONS
Figure 1. Đorde Andrejević Kun, Column, oil on canvass, $185 \times 216 \mathrm{~cm}$, SIV, Belgrade (Source: ex Federal Executive Council (Yugoslavia), today Palace of Serbia). Belgrade

Figure 2. Marshal Tito visiting wounded fighters in the Main Military Hospital in Belgrade, $1^{\text {st }}$ January 1945. (Source: Published in: D. Đurović (1966), Nova Jugoslavija1941-1945, Beograd: NIP "Mladost”, p. 64).

Figure 3. John Phillips, Tito, in the White Palace Signing his Speech Collection immediately After the Second World War (Source: Published in: Filips, Dž. (1983). Jugoslovenska priča (1943 - 1983). Beograd, Zagreb: Jugoslovenska revija, Mladost, p. 129). 
МАРТА М. ВУКОТИЋ ЛАЗАР

УНИВЕРЗИТЕТ У ПРИШТИНИ СА ПРИВРЕМЕНИМ СЕДИШТЕМ

У КОСОВСКОЈ МИТРОВИЦИ, ФИЛОЗОФСКИ ФАКУЛТЕТ

КАТЕДРА ЗА ИСТОРИЈУ УМЕТНОСТИ

ОЛИВЕРА С. МАРКОВИЋ САВИЋ

УНИВЕРЗИТЕТ У ПРИШТИНИ СА ПРИВРЕМЕНИМ СЕДИШТЕМ

У КОСОВСКОЈ МИТРОВИЦИ, ФИЛОЗОФСКИ ФАКУЛТЕТ

КАТЕДРА ЗА СОЦИОЛОГИЈУ

САЖЕТАК

КУЛТУРНА ПОЛИТИКА И СЕЋАњЕ НА БОРЦЕ НАРОДНООСЛОБОДИЛАЧКОГ РАТА: ЦЕНТРАЛНА УЛОГА ВОЈСКЕ У ПОЛИТИЧКОЈ ЛЕГИТИМИЗАЦИЈИ НОВЕ ПОЛИТИЧКЕ СТРУКТУРЕ

Борци Народноослободилачког рата (НОР) уживали су друштвени престиж, а споменици погинулим борцима били су у функцији идеолошких интереса тадашње владајуће класе. Циљ рада је да прикаже спону између живих друштвених актера и изабраних мртвих актера (бораца НОР-а, партизана) кроз употребу антрополошке стрепње од прекида живота преко метафоричке бесмртности и вечног сећања. Ово је у суштини био привид за идеолошки темељ, посебну тематску и идеолошку оријентацију скулптуре у јавном простору. Путем симболичких садржаја, у овом случају споменика, смрт се приказује као прелаз, тј. нови почетак живота, а не његов крај. Активно учешће великог броја уметника из свих делова бивше Југославије у јединицама партизанске војске у НОР-у, феномен је који недвосмислено сведочи о спрези њихове политичке опредељености и уметничког стваралаштва, који ће посебно снажан замах добити непосредно након Ослобођења. Најважнији друштвени задатак у Социјалистичкој Федеративној Републици Југославији (СФРЈ) био је неговање револуционарне традиције, што се првенствено огледало у подизању спомен-обележја, потом (пре)именовању назива градова Титовим именом или именима народних хероја, као и улица, школа, фабрика, али и организовањем маршева до места где су се одвијале знамените битке или партизанска заседања током НОР-а итд. Рад се, између осталог, бави изузетно плодном продукцијом вајара у ослобођеној земљи, посебно са аспекта опсежне друштвене наруџбине која је уједно подстицала и омогућавала брз и разнородан развој јавних споменика у градском простору и то на тлу целе бивше Југославије, чији је modus operandi био преобликовање политичке 
и идеолошке мапе Нове Југославије и идеолошко-политички обрачун са „рецидивима прошлости“.

КљУЧНЕ РЕЧИ: борци; НОР; НОБ; партизани; ФНРЈ; СФРЈ; идеологија; скулптура; јавни градски простор.

Овај чланак је објављен и дистрибуира се под лиценцом Creative Commons Ауторство-Некомерцијално Међународна 4.0 (CC BY-NC 4.0 |

https://creativecommons.org/licenses/by-nc/4.0/).

This paper is published and distributed under the terms and conditions of the Creative Commons Attribution-NonCommercial International 4.0 licence (CC BY-NC 4.0 | https://creativecommons.org/licenses/by-nc/4.0/). 